\title{
Effect of Trawling and Habitat on Mercury Concentration in Juvenile Red Snapper from the Northern Gulf of Mexico
}

\author{
R. J. DAVID WELLS*1 \\ Department of Oceanography and Coastal Sciences, \\ Louisiana State University, Baton Rouge, Louisiana 70803, USA \\ Matthew M. Chumchal \\ Department of Biology, Texas Christian University, Fort Worth, Texas 76129, USA \\ JAMES H. COWAN, JR. \\ Department of Oceanography and Coastal Sciences, \\ Louisiana State University, Baton Rouge, Louisiana 70803, USA
}

\begin{abstract}
We evaluated mercury $(\mathrm{Hg})$ contamination in juvenile red snapper Lutjanus campechanus $(<250 \mathrm{~mm}$ total length) as an indicator of $\mathrm{Hg}$ pollution on the northern Gulf of Mexico (GOM) continental shelf. Specifically, we examined the effects of fish size, commercial shrimp trawling, and habitat type on total $\mathrm{Hg}$ concentrations and stable nitrogen isotope ratios $\left(\delta^{15} \mathrm{~N}\right.$; a proxy for trophic position) in red snapper. Red snapper $\mathrm{Hg}$ concentrations and $\delta^{15} \mathrm{~N}$ values were positively and significantly correlated with fish size. In addition, red snapper collected over trawled habitats had significantly higher $\mathrm{Hg}$ concentrations and $\delta^{15} \mathrm{~N}$ values than did red snapper collected from similar, nontrawled habitats. Red snapper also exhibited habitatspecific differences in $\mathrm{Hg}$ concentrations and $\delta^{15} \mathrm{~N}$ values, but differences were size dependent and generally small. Our study suggests that the $\mathrm{Hg}$ concentrations of juvenile red snapper in the northern GOM are elevated in areas where commercial shrimp trawling occurs, possibly due to increases in both red snapper trophic position and bioavailable $\mathrm{Hg}$ in trawled areas. Additional studies are needed to determine whether $\mathrm{Hg}$ concentrations are elevated in fish from trawled areas in other marine ecosystems.
\end{abstract}

Mercury $(\mathrm{Hg})$ is a toxic heavy metal that accumulates in food webs and has increased in the environment primarily because of anthropogenic activities (NRC 2000; Pacyna and Pacyna 2005). Coal burning releases inorganic $\mathrm{Hg}$ into the atmosphere, where it resides until it is deposited onto the earth's surface (Jackson 1997). In marine ecosystems, sulfate-reducing bacteria (SRB) associated with sediments convert inorganic $\mathrm{Hg}$, the most common form in the environment, to highly toxic methylmercury ( $\mathrm{MeHg}$; Morel et al. 1998; Ullrich et al. 2001; Mason and Gill 2005). Production of $\mathrm{MeHg}$ is related to factors that influence geochemical conditions and microbial activity in the sediment, such as redox conditions, sediment grain size, organic matter content, and density of infaunal burrows (Bloom et al. 1999; Mason and Lawrence 1999; Hammerschmidt and Fitzgerald 2004; Benoit et al. 2006). Organisms at the base of the food web, such as phytoplankton, absorb $\mathrm{MeHg}$ directly from the water (Miles et al. 2001). Consumers, including fish,

\footnotetext{
* Corresponding author: wellsr@tamug.edu

${ }^{1}$ Present address: Department of Marine Biology, Texas A\&M University, Galveston, Texas 77551, USA
}

Received December 19, 2007; accepted June 17, 2008 Published online December 15, 2008 are exposed to $\mathrm{MeHg}$ primarily through the diet (Hall et al. 1997; Tsui and Wang 2004), and fish with high trophic positions have elevated concentrations of $\mathrm{MeHg}$ (Wiener et al. 2003).

The primary source of $\mathrm{MeHg}$ in humans is consumption of $\mathrm{Hg}$-contaminated fish (NRC 2000), and $\mathrm{MeHg}$ has negative effects on human health (NRC 2000; Clarkson 2002). Despite the fact that the majority of fish consumed by humans are marine (Munthe et al. 2007), most studies investigating factors that affect $\mathrm{MeHg}$ contamination in fish have focused on freshwater lakes (Wiener et al. 2003; Munthe et al. 2007). Understanding the factors that regulate $\mathrm{MeHg}$ contamination in marine fish is critical, because many commercial and recreational fish species have $\mathrm{MeHg}$ concentrations at or above the recommended levels for safe consumption (NRC 2000; USEPA 2006).

Coastal marine ecosystems like the Gulf of Mexico (GOM) continental shelf are subject to large-scale anthropogenic sediment disturbance from commercial shrimp trawling. Similar to other anthropogenic activities that disturb the sediment (e.g., dredging), commercial shrimp trawling may enhance $\mathrm{MeHg}$ production by altering geochemical conditions and microbial activity in the sediment (Bloom and Lasorsa 1999; Eggleton and Thomas 2004). In addition to 


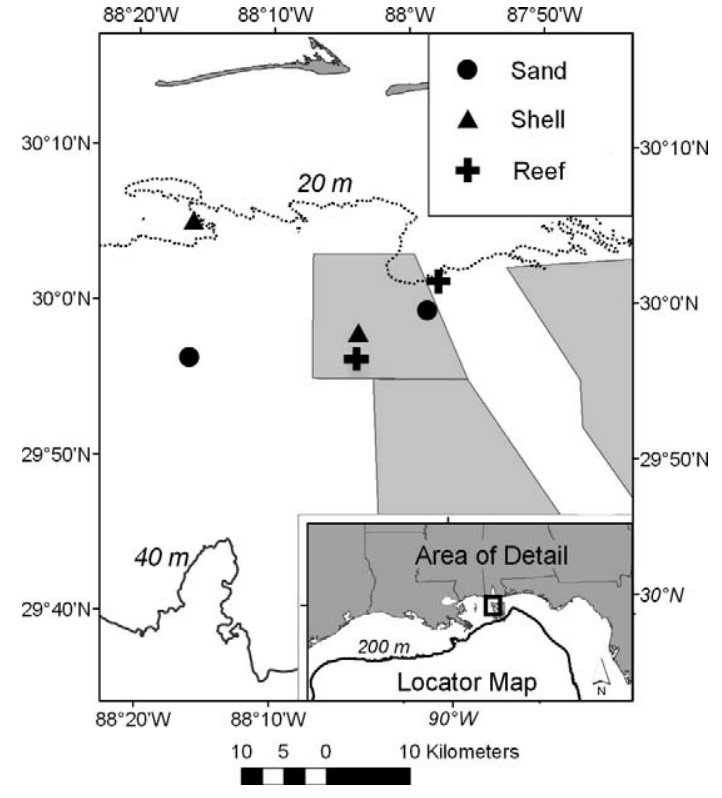

Figure 1.-Study region on the northern Gulf of Mexico continental shelf, where the effect of trawling on mercury concentrations and stable isotope ratios in juvenile red snapper was examined. The 20-, 40-, and 200-m (map inset) depth contours are shown; the 200-m contour represents the shelf edge. Sampling sites (sand, shell, and reef habitat types) are represented by symbols, and the artificial reef permit area (de facto nontrawled subregion) is indicated by shading.

affecting $\mathrm{MeHg}$ production, trawling may affect $\mathrm{MeHg}$ concentrations in fish by altering food web structure (Thrush and Dayton 2002).

Coastal marine ecosystems also exhibit large spatial variability in habitat types (Thrush and Dayton 2002). The northern GOM continental shelf is largely dominated by mud and sand habitat (Kennicutt et al. 1995) and also contains natural hard-bottom habitats in the form of reef banks, ledges, and shell rubble ridges that exist on the shallow $(<40 \mathrm{~m})$ inner shelf (Schroeder et al. 1988; Dufrene 2005). Methylmercury production and fish contamination may differ with respect to habitat because the redox conditions, organic content, and invertebrate communities within sediments differ among habitats (Dufrene 2005; Wells et al. 2008c).

Habitat use by red snapper Lutjanus campechanus has been well studied on the northern GOM continental shelf. Juvenile red snapper (defined here as age- 0 or age-1 sexually immature fish $<250 \mathrm{~mm}$ total length [TL]; Woods et al. 2007) primarily use sand, shell rubble, and low-relief microhabitats (e.g., rubble patches, debris; Workman and Foster 1994; Szedlmayer and Howe 1997; Patterson et al. 2005). Because juvenile red snapper exhibit habitat and site fidelity (Workman et al. 2002) and are low-level consumers (Wells et al. 2008b), their $\mathrm{Hg}$ concentrations can be used to indicate $\mathrm{MeHg}$ bioavailability in habitats where they reside (Lindqvist et al. 1991; Bank et al. 2007).

In this study, we evaluated $\mathrm{Hg}$ concentrations in juvenile red snapper as an indicator of $\mathrm{Hg}$ pollution in marine fish inhabiting the northern GOM continental shelf. Specifically, we wanted to determine whether $\mathrm{Hg}$ concentrations in juvenile red snapper were related to commercial shrimp trawling presence and habitat type. We also examined stable nitrogen isotope ratios $\left(\delta^{15} \mathrm{~N}\right.$; a proxy for trophic position) in juvenile red snapper to determine whether differences in trophic position could explain possible differences in $\mathrm{Hg}$ concentrations among study sites.

\section{Methods}

Study site.-Red snapper were collected from a northern GOM continental shelf region consisting of two subregions (Figure 1). The first subregion was an area of open shelf that was exposed to commercial shrimp trawling. Wells et al. (2008c) divided commercial shrimp trawling effort (J. Nance, National Oceanic and Atmospheric Administration [NOAA], National Marine Fisheries Service [NMFS], Galveston, Texas, personal communication) by bottom surface area (Patella 1975) and conservatively estimated that trawling effort in this subregion was sufficient to disturb the entire seafloor at least once per year. Electronic logbook data from shrimp fishing vessels indicate that some locations in the subregion are targeted with much-greater frequency (NRC 2002). The second subregion was an extensive $\left(>3,000-\mathrm{km}^{2}\right)$ artificial reef permit area that was directly adjacent to the subregion exposed to trawling (Figure 1). The artificial reef permit area served as a de facto nontrawled area, because shrimp vessels voluntarily avoid it due to the possibility of losing their nets by snagging them on reef structures (Link 1997; NRC 2002). As such, the presence of the artificial reef permit area provided a unique opportunity to evaluate the effect of trawling on $\mathrm{Hg}$ concentrations in fish. We assumed that no or limited trawling occurred in the artificial reef permit area, but there is some uncertainty surrounding this assumption. Trawler entry into the artificial reef permit area is possible because no regulations or enforcing mechanisms are currently in place to exclude shrimp vessels from the area. Distributional shrimp trawl effort data indicate that extensive trawling effort occurs outside the artificial reef permit area, while little to no effort occurs within this area (NRC 2002). In addition, Link (1997) calculated that the addition of the artificial reef permit 
area annexed the largest portion of untrawlable bottom to the northern GOM inner shelf. A second assumption in this study was that the presence of artificial reefs did not affect $\mathrm{Hg}$ concentrations or feeding patterns $\left(\delta^{15} \mathrm{~N}\right)$ of red snapper. This is supported by a preliminary survey indicating that $\mathrm{Hg}$ concentrations did not differ between red snapper collected from natural reefs and those collected from artificial reefs (M.M.C., personal observation). In addition, two studies found that reefassociated organisms made up a small percentage of the diets of red snapper associated with artificial and natural reefs (McCawley et al. 2006; Wells et al. 2008 b). To minimize any potential effect of artificial reefs, we selected study areas in which sonar surveys indicated an absence of artificial reefs (Dufrene 2005).

Within each subregion, we collected fish from three habitat types: sand with interspersed mud, shell rubble ridges, and high-relief ( $>2-\mathrm{m}$ ) natural reefs (Figure 1). Seabed characterization within each subregion was performed with digital side-scan sonar and was groundtruthed with box core sediment analysis during previous studies (Dufrene 2005; Patterson et al. 2005). Similar habitat types inside and outside the artificial reef permit area contained sediment with similar grain size, organic content, and calcium carbonate content. Habitat types exhibited limited variation in mean depth. Mean depths for trawled habitats were $30 \mathrm{~m}$ for sand habitat, $18 \mathrm{~m}$ for shell habitat, and $24 \mathrm{~m}$ for reef habitat; depths for nontrawled habitats were $25 \mathrm{~m}$ for sand habitat, $26 \mathrm{~m}$ for shell habitat, and $29 \mathrm{~m}$ for reef habitat.

Field sampling.--Red snapper were collected during three sampling cruises in May, August, and October 2004. Within each habitat $\times$ trawl combination, we randomly selected three fish sampling sites (total of 18 sampling sites in the study) that were separated by $1-5$ $\mathrm{km}$. The 18 sampling sites were fixed for the duration of the study, and each site was sampled during each cruise. All sampling was performed during daylight hours (from $30 \mathrm{~min}$ after sunrise to $30 \mathrm{~min}$ before sunset).

Red snapper were collected with otter trawls. Trawl gear included a single net (width $=12.8 \mathrm{~m}$; mesh size of body $=4 \mathrm{~cm}$; mesh size of cod-end lining $=0.7 \mathrm{~cm}$ ) towed at approximately $4.6 \mathrm{~km} / \mathrm{h}$ for $10 \mathrm{~min} / \mathrm{sample}$. Trawls were towed along the edges of the reef habitats to avoid damaging immobile fauna (i.e., sponges, corals) or hanging the net. Trawling is an effective method of collecting juvenile red snapper (Wells et al. 2008a); unlike commercial shrimp trawling, our collections were one-time disturbance events that affected a limited area. We were also able to use otter trawls in the artificial reef permit area, because we first conducted a side-scan sonar survey to ensure that the area was free of hangs. Otter trawls primarily capture juveniles, and use of additional sampling gears that target adults was beyond the scope of this study.

After collections were made, red snapper were transported to the laboratory and stored at $-80^{\circ} \mathrm{C}$. In the laboratory, the total length (TL) of each fish was measured to the nearest millimeter. Red snapper epaxial muscle tissue was dissected from the left side and dried in a drying oven (Yamato, Orangeburg, New York; Model DX 600) at $60^{\circ} \mathrm{C}$ for $24 \mathrm{~h}$ or until the sample reached a constant weight; the tissue was then homogenized with a ball-mill grinder (Dentsply International, York, Pennsylvania). Ground muscle tissue was stored in clean glass scintillation vials until $\mathrm{Hg}$ or $\delta^{15} \mathrm{~N}$ analysis was performed.

Mercury analysis.-Total $\mathrm{Hg}$ was used as a proxy for $\mathrm{MeHg}$, because $97 \%$ of total $\mathrm{Hg}$ in red snapper tissue is in the form of MeHg (Bank et al. 2007). Total $\mathrm{Hg}$ analysis was performed with a direct $\mathrm{Hg}$ analyzer (Milestone, Inc., Monroe, Connecticut; DMA-80) that uses thermal decomposition, gold amalgamation, and atomic absorption spectrometry (USEPA 1998). A calibration curve was generated using three reference materials from the Institute for National Measurement Standards (National Research Council of Canada): MESS-3 (marine sediment: certified value $=91 \pm 9 \mathrm{ng}$ of total $\mathrm{Hg} / \mathrm{g}$ of dry weight [mean $\pm 95 \%$ confidence interval]), PACS-2 (marine sediment: certified value = 3,040 $\pm 200 \mathrm{ng} / \mathrm{g}$ ), and DORM-2 (muscle of spiny dogfish Squalus acanthias: certified value $=4,640 \pm$ $260 \mathrm{ng} / \mathrm{g}$ ). Quality assurance included reference samples, duplicate samples, and blanks. Reference samples (MESS-3 or TORT-2, hepatopancreas of the American lobster Homarus americanus) were analyzed every 10 samples, and the mean percent recovery was $103 \pm 4 \%$ (mean $\pm \mathrm{SD}$; range $=96-111 \% ; n=21)$. Duplicate samples were analyzed every 20 samples, and the mean relative percent difference was $1.19 \pm$ $1.06 \%$ (range $=0.05-1.45 \% ; n=9$ ). Blanks (empty quartz sample boats) were analyzed every 20 samples, and the mean $\mathrm{Hg}$ content was $0.06 \pm 0.05 \mathrm{ng}$ (range $=$ 0.01-0.19 ng; $n=10$ ).

Stable isotope analysis.-The $\delta^{15} \mathrm{~N}$ in red snapper was used as a proxy for red snapper trophic position (Bank et al. 2007). Stable nitrogen isotopes are used differentially in cellular processes, resulting in a predictable increase in the heavy isotope $\left({ }^{15} \mathrm{~N}\right)$ relative to the light isotope $\left({ }^{14} \mathrm{~N}\right)$ with each increase in trophic level $(\approx 3-4 \%$; Minagawa and Wada 1984; Peterson and Fry 1987).

Ground muscle tissue (4-5 mg) was placed in a tin boat with $10 \mathrm{mg}$ of precombusted vanadium pentoxide $\left(\mathrm{V}_{2} \mathrm{O}_{5}\right)$. The $\mathrm{N}$ isotopic composition of red snapper muscle tissue was determined with a Finnigan MAT 
DeltaPlus continuous-flow stable isotope mass spectrometer (Thermo Fisher Scientific, Inc., Waltham, Massachusetts) attached to a Carlo Erba elemental analyzer (CE Elantech, Lakewood, New Jersey) at Louisiana State University (Fry 2007). Nitrogen isotopic values are reported relative to atmospheric $\mathrm{N}_{2}$ using the standard equation:

$$
\delta_{\text {sample }}(\%)=\left(R_{\text {sample }} / R_{\text {standard }}-1\right) \times 1,000,
$$

where $R$ represents the ${ }^{15} \mathrm{~N}:{ }^{14} \mathrm{~N}$ ratio.

Data analysis.-Linear models were used to relate red snapper $\mathrm{Hg}$ concentrations or $\delta^{15} \mathrm{~N}$ values to TL ( $n$ $=125$ ). The number of juveniles (from all habitat $\times$ trawl combinations) included in analyses was 52 from May sampling, 40 from August sampling, and 33 from October sampling. Two-factor analysis of covariance (ANCOVA) fixed-effects models were used to test for the effects of habitat and trawling on red snapper $\mathrm{Hg}$ concentration or $\delta^{15} \mathrm{~N}$, and fish TL was included as the covariate. A posteriori differences among means were detected with Tukey's honestly significant difference test (Day and Quinn 1998). To determine whether differences in $\mathrm{Hg}$ concentrations between trawled and nontrawled subregions could be explained by $\delta^{15} \mathrm{~N}$ values, we used a two-factor ANCOVA with habitat and trawling as fixed factors and $\delta^{15} \mathrm{~N}$ values and TL as the covariates (Baron and Kenny 1986).

We used an ANCOVA design because TL is correlated with $\mathrm{Hg}$ concentrations in red snapper (Bank et al. 2007) and because TL differed between treatment groups in this study. In ANCOVA models, regression analysis is used to remove the covariate's effect from the unexplained variability in the response variable. The final ANCOVA tests the difference between treatment means $\left(\mathrm{Hg}\right.$ or $\left.\delta^{15} \mathrm{~N}\right)$ adjusted for the effect of the covariate (Quinn and Keough 2002). Linearity was tested for each ANCOVA model; full ANCOVA models were first examined with all factors, covariates, and covariate $\times$ factor interactions included. Nonsignificant interaction terms $(P>0.05)$ were then removed from the models, and only the reduced models were used for statistical interpretations.

The homogeneous variance assumption was examined with residual plots, and normality was examined using a probability plot of the residuals versus the expected values. Two outliers exceeded the traditional interquartile range (IQR) test. The IQR test is used to identify extreme outliers and was calculated by use of the inner- and outer-fence method (Ott 1993; Brant 1990). The two outliers were deleted from the data set to meet assumptions of homogeneous variance and normality, but results were not affected by removal of these outliers. All analyses were performed using the
Statistical Analysis System (SAS Institute 2006) and a significance level of 0.05 .

\section{Results}

Juvenile red snapper from all sites had a mean ( $\pm \mathrm{SE}$ ) $\mathrm{Hg}$ concentration of $148.3 \pm 4.8 \mathrm{ng} / \mathrm{g}$ of dry weight and a mean $\delta^{15} \mathrm{~N}$ value of $13.6 \pm 0.1 \%$. For samples pooled from all locations, $\mathrm{Hg}$ concentrations and $\delta^{15} \mathrm{~N}$ values were positively and significantly correlated with TL (Figure $2 ; \mathrm{Hg}=13.77+0.94 \mathrm{TL}, R^{2}$ $=0.76, P<0.001 ; \delta^{15} \mathrm{~N}=13.04+0.01 \mathrm{TL}, R^{2}=0.25$, $P<0.001)$. A significant positive correlation was also observed between $\mathrm{Hg}$ concentration and $\delta^{15} \mathrm{~N}$ (Figure $3 ; \log _{10} \mathrm{Hg}=-3.09+\left[0.39 \times \delta^{15} \mathrm{~N}\right], R^{2}=0.46, P<$ 0.001).

Red snapper that were collected over trawled habitats had a significantly higher $\mathrm{Hg}$ concentrations (least-squares mean $=150.9 \pm 4.4 \mathrm{ng} / \mathrm{g}$ ) than fish that were collected from nontrawled habitats (132.2 \pm 3.7 ng/g; Figure 4a; Table 1). In general, Hg concentrations in red snapper collected from a given habitat type were higher for fish sampled in the trawled subregion than for those sampled in the nontrawled subregion (Figure 5; Table 2); post hoc comparisons indicated a significant difference between fish from trawled and nontrawled shell-type habitats $(P=0.007)$. We detected a significant habitat effect and habitat $\times$ TL interaction effect on $\mathrm{Hg}$ concentrations in red snapper (Table 1). The significant interaction indicates that the effect of habitat type on red snapper $\mathrm{Hg}$ concentrations is dependent on TL (Figure 4b). For the smallest sizeclasses of red snapper, $\mathrm{Hg}$ values were highest in fish collected from sand habitat, intermediate in fish from shell habitat, and lowest in fish from reef habitat. However, for the largest size-classes, the order was reversed (i.e., $\mathrm{Hg}$ values were in descending order for reef, shell, and sand habitats).

Red snapper collected from trawled habitats had a significantly higher $\delta^{15} \mathrm{~N}$ value (least-squares mean $=$ $13.8 \pm 0.1 \%$ ) than those collected from nontrawled habitats $(13.5 \pm 0.1 \%$; Figure $6 \mathrm{a}$; Table 1$)$. Similar to the results for $\mathrm{Hg}$ concentrations, the red snapper $\delta^{15} \mathrm{~N}$ value within a given habitat type was higher for the trawled region than for the nontrawled region, and post hoc comparisons indicated a significant difference between fish from trawled and nontrawled shell habitats $(P<0.001$; Figure 5; Table 2). The habitat effect and habitat $\times$ TL interaction effect on $\delta^{15} \mathrm{~N}$ values were significant (Table 1). The significant interaction indicates that the effect of habitat on red snapper $\delta^{15} \mathrm{~N}$ depends on TL (Figure 6b). For the smallest size-classes of red snapper, $\delta^{15} \mathrm{~N}$ values were highest in fish collected from reef habitat, intermediate in fish from sand habitat, and lowest in fish from shell 


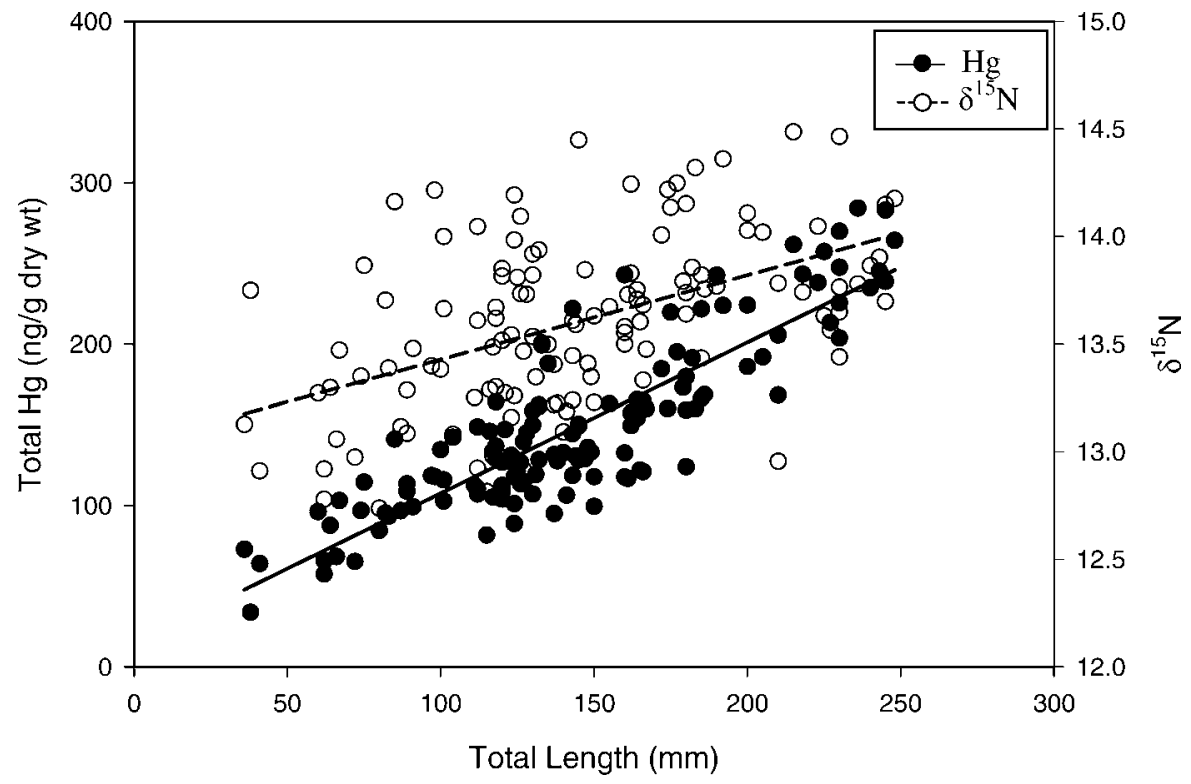

FIGURE 2.- Relationship between total mercury $(\mathrm{Hg})$ concentration (ng/g of dry weight) or stable nitrogen isotope ratio $\left(\delta^{15} \mathrm{~N}\right.$; $\%$ ) and total length $(\mathrm{mm})$ of juvenile red snapper collected from all three habitat types (sand, shell, and natural reef) of the northern Gulf of Mexico continental shelf in 2004.

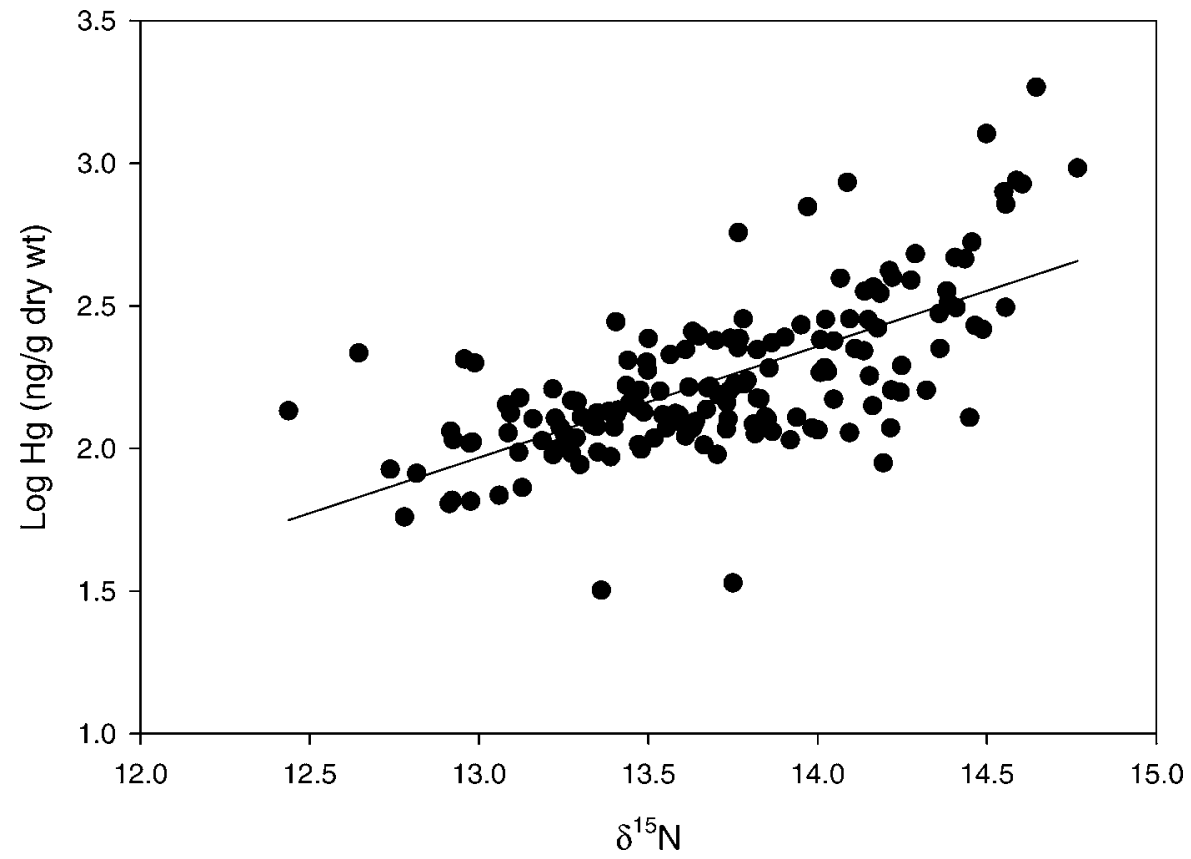

FIGURE 3.- Relationship between $\log _{10}$ (total mercury $[\mathrm{Hg}]$ concentration) (ng/g of dry weight) and stable nitrogen isotope ratio $\left(\delta^{15} \mathrm{~N} ; \%\right.$ of juvenile red snapper collected from all three habitat types (sand, shell, and natural reef) of the northern Gulf of Mexico continental shelf in 2004. 

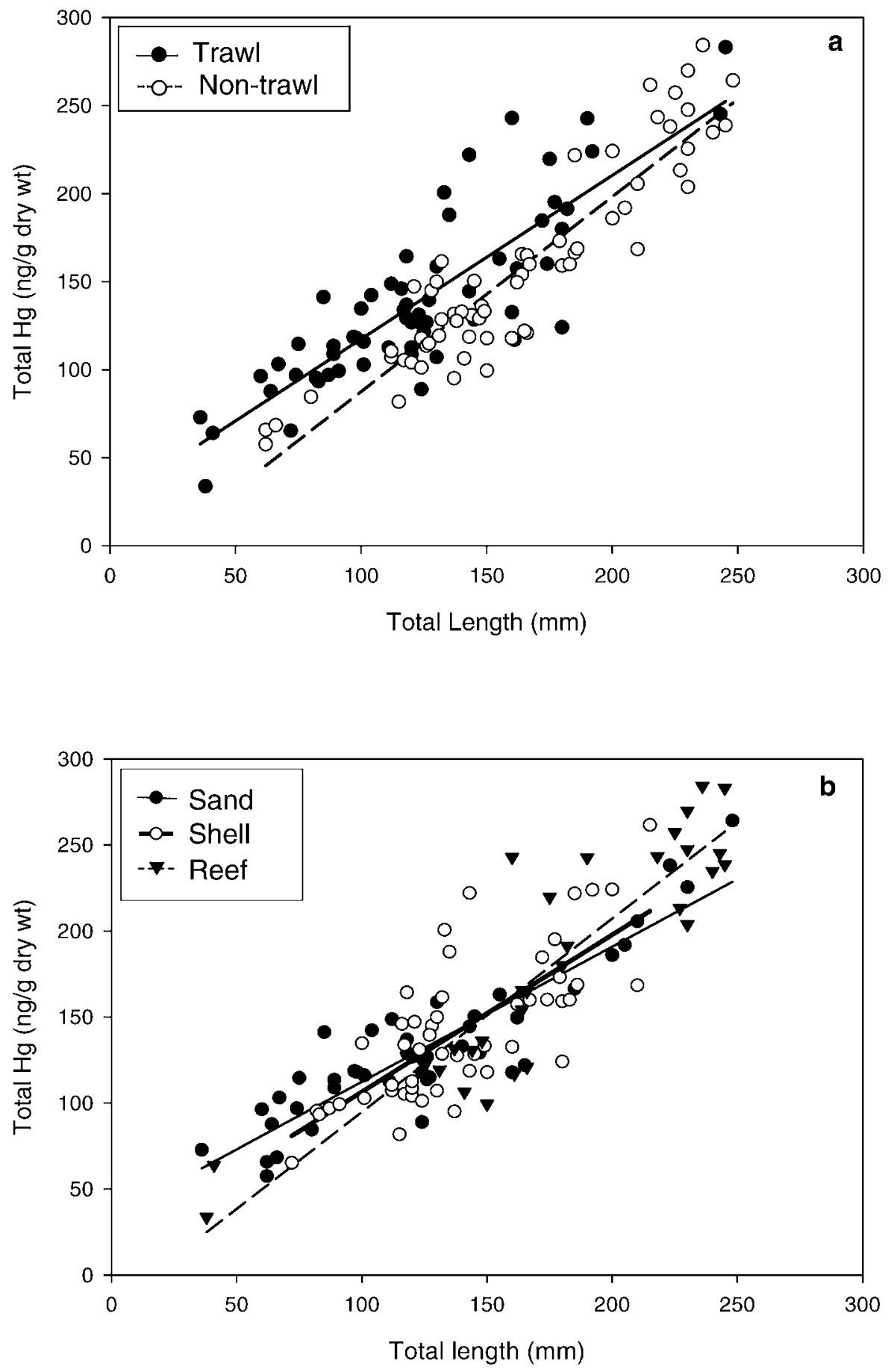

FIGURE 4.-Relationship between total mercury ( $\mathrm{Hg}$ ) concentration (ng/g of dry weight) and total length (mm) of juvenile red snapper collected in 2004 from (a) trawled and nontrawled subregions and (b) sand, shell, and natural-reef habitat types of the northern Gulf of Mexico continental shelf. 
habitat. The order of $\delta^{15} \mathrm{~N}$ values among habitats was reversed for the largest size-classes.

Because $\mathrm{Hg}$ concentrations were positively related to $\delta^{15} \mathrm{~N}$ and because $\delta^{15} \mathrm{~N}$ was elevated in trawled areas, $\delta^{15} \mathrm{~N}$ may have acted as a mediating variable (Baron and Kenny 1986). A mediating variable is one that represents the generative mechanism through which the focal independent variable (i.e., trawling) is able to influence the dependent variable of interest (i.e., $\mathrm{Hg}$; Baron and Kenny 1986). To determine whether $\delta^{15} \mathrm{~N}$ was a mediating variable for the effect of trawling on $\mathrm{Hg}$ concentrations, we used the approach recommended by Baron and Kenny (1986) and regressed $\mathrm{Hg}$ on both trawling and $\delta^{15} \mathrm{~N}$ values. The model also included habitat and TL. The effect of $\delta^{15} \mathrm{~N}$ value was not significant $(F=0.11 ; \mathrm{df}=1,119 ; P=0.74)$, but we found a significant main effect of trawling $(F=$ 18.3; $\mathrm{df}=1,119 ; P<0.001)$ on $\mathrm{Hg}$ concentrations when all other variables were included in the model. This result indicated that $\delta^{15} \mathrm{~N}$ was not a mediating variable; it could only have been considered a mediating variable if trawling had produced no effect on $\mathrm{Hg}$ concentrations when $\delta^{15} \mathrm{~N}$ values were controlled (Baron and Kenny 1986).

\section{Discussion}

The $\mathrm{Hg}$ concentrations in red snapper muscle tissue increased with fish TL. Previous studies have repeatedly found a positive correlation between $\mathrm{Hg}$ concentrations and fish size (McClain et al. 2006; Cai et al. 2007). Because fish increase in both age and trophic position as they grow, it is difficult to discern whether the increase in Hg observed in this study resulted from biomagnification or from time-related bioaccumulation. Nevertheless, the significant relationship between $\delta^{15} \mathrm{~N}$ and TL indicates that trophic position also increases with size; thus, biomagnification is a possible explanation for the observed increase in $\mathrm{Hg}$ with increasing TL.

The Hg concentrations in juvenile red snapper were elevated in areas of the northern GOM continental shelf where shrimp trawling occurred. To our knowledge, this is the first study to document a positive relationship between the presence of trawling and fish $\mathrm{Hg}$ concentration. This study adds to a growing body of evidence that anthropogenic disturbance of sediments leads to increased contaminant concentrations in marine organisms (Eggleton and Thomas 2004). Our study was limited to one nontrawled subregion because of the limited availability of additional nontrawled regions in the northern GOM. The lack of replication limits our ability to generalize results from this study to the entire GOM shelf or to other marine ecosystems. Future studies should compare fish $\mathrm{Hg}$ concentrations between
TABLE 1.-Results of reduced analysis of covariance models investigating the effects of habitat type (sand, shell, and reef), presence of trawling, and fish total length (TL; mm) on the total mercury $(\mathrm{Hg})$ concentration ( $\mathrm{ng} / \mathrm{g}$ of dry weight) and stable nitrogen isotope ratio $\left(\delta^{15} \mathrm{~N} ; \%\right)$ in juvenile red snapper collected in 2004 from the northern Gulf of Mexico continental shelf.

\begin{tabular}{llccr}
\hline $\begin{array}{c}\text { Dependent } \\
\text { variable }\end{array}$ & \multicolumn{1}{c}{$\begin{array}{c}\text { Significant } \\
\text { factors }\end{array}$} & $\begin{array}{c}\text { df (factor, } \\
\text { model error) }\end{array}$ & \multicolumn{1}{c}{$F$} & \multicolumn{1}{c}{$P$} \\
\hline $\mathrm{Hg}$ & Trawling & 1,118 & 21.1 & $<0.001$ \\
& Habitat type & 2,118 & 4.99 & 0.008 \\
& Total Length (TL) & 1,118 & 406 & $<0.001$ \\
& Habitat type $\times \mathrm{TL}$ & 2,118 & 3.76 & 0.026 \\
$\delta^{15} \mathrm{~N}$ value & Trawling & 1,118 & 34.5 & $<0.001$ \\
& Habitat type & 2,118 & 6.51 & 0.002 \\
& TL & 1,118 & 77.3 & $<0.001$ \\
& Habitat type $\times \mathrm{TL}$ & 2,118 & 8.95 & $<0.001$ \\
\hline
\end{tabular}

trawled and nontrawled areas of other marine ecosystems to determine whether the relation between trawling and elevated $\mathrm{Hg}$ concentrations is generalizable.

The Hg concentrations may have been higher in trawled areas because physical disturbance of the sediments led to an increase in $\mathrm{MeHg}$ production and availability. Trawling mixes sediment from the anoxic zone into surface water (Thrush and Dayton 2002), possibly resulting in the release of sediment- and porewater-associated $\mathrm{MeHg}$ and increasing its availability for incorporation into the food web (Eggleton and Thomas 2004). In addition, sediment mixing due to trawling causes translocation of organic carbon to the anoxic zone (Thrush and Dayton 2002) and may have stimulated the MeHg-producing SRB (Fitzgerald and Lamborg 2003). Bloom and Lasorsa (1999) examined $\mathrm{MeHg}$ concentrations in the water column above dredge spoil and found that both mechanisms probably contributed to elevated $\mathrm{Hg}$ concentrations. In one of the only studies to examine $\mathrm{Hg}$ concentrations in biota after anthropogenic sediment disturbance, Bellas et al. (2007) hypothesized that $\mathrm{Hg}$ in caged filter-feeding mussels was elevated after dredging due to mobilization of bioavailable $\mathrm{Hg}$ to the water column. Studies are needed to determine whether $\mathrm{MeHg}$ concentrations are higher in the sediment and water column of trawled GOM areas than in nontrawled areas.

An alternative but not mutually exclusive hypothesis for explaining the elevated $\mathrm{Hg}$ concentrations observed in red snapper from trawled areas is an increase in fish trophic position associated with sediment disturbance (i.e., trophic position acting as a mediator variable). Trophic position is positively correlated with $\mathrm{Hg}$ concentrations in fish (Cabana and Rasmussen 1994; Cai et al. 2007; this study), and we detected an enhancement of both trophic position (i.e., elevated $\delta^{15} \mathrm{~N}$ ) and $\mathrm{Hg}$ concentrations in red snapper collected 

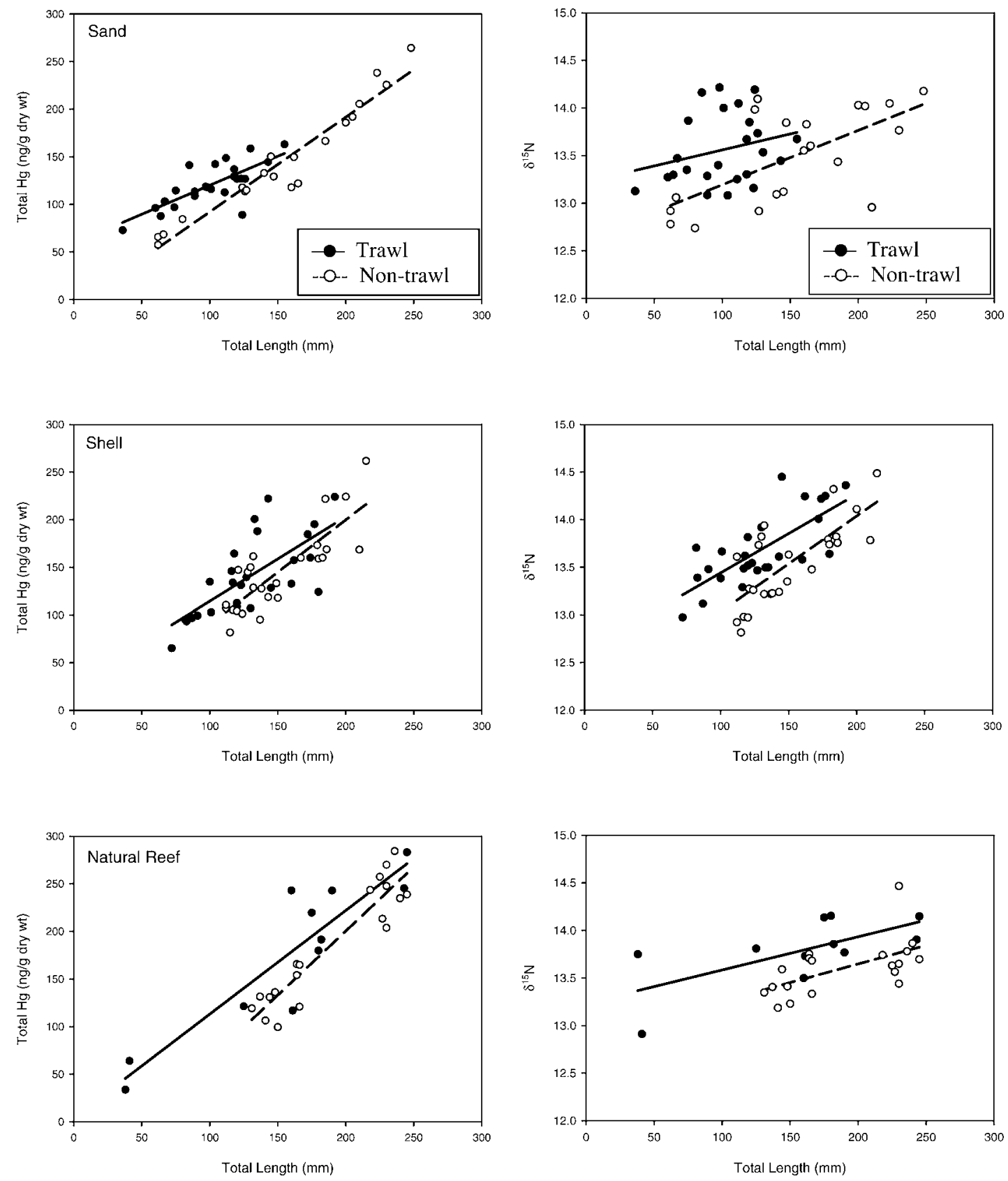

FIGURE 5.- Relationship between total mercury $(\mathrm{Hg})$ concentration $\left(\mathrm{ng} / \mathrm{g}\right.$ of dry weight) or stable nitrogen isotope ratio $\left(\delta^{15} \mathrm{~N}\right.$; $\%$ ) and total length $(\mathrm{mm})$ of juvenile red snapper collected in 2004 from the sand, shell, and natural-reef habitat types within trawled and nontrawled subregions of the northern Gulf of Mexico continental shelf.

from trawled habitats. The enriched $\delta^{15} \mathrm{~N}$ in fish from trawled areas may be attributed to an increase in the opportunity for red snapper to prey upon benthic organisms that have been injured or killed by trawling. Kenchington et al. (2005) found that changes in the diets of demersal fishes were caused by prey availability alterations brought about by trawling disturbances. It was demonstrated that large fish predators rapidly moved into recently trawled areas to feed and take advantage of the increase in foraging opportunities (Wassenberg and Hill 1987; Kaiser and Spencer 1994). In the GOM, a similar phenomenon 
was observed wherein bottlenose dolphins Tursiops truncates preyed on fishes that were exiting trawl openings (University of Georgia Marine Extension Service and NMFS Harvesting Branch 2003). To test the hypothesis that elevated $\mathrm{Hg}$ concentrations in fish from trawled areas were related to trophic position, we used Baron and Kenny's (1986) approach for identifying mediator variables. We found that $\delta^{15} \mathrm{~N}$ values did not have a significant effect on $\mathrm{Hg}$ concentrations, which indicates that enhanced $\delta^{15} \mathrm{~N}$ in trawled areas was not responsible for the elevated $\mathrm{Hg}$ concentrations in fish from these areas. Therefore, we hypothesize that differences in $\mathrm{MeHg}$ bioavailability between trawled and nontrawled subregions were responsible for differences in $\mathrm{Hg}$ concentrations.

A key assumption of our interpretation of red snapper $\delta^{15} \mathrm{~N}$ values is that the $\delta^{15} \mathrm{~N}$ values near the base of the food web for a given habitat type are similar between trawled and nontrawled subregions. Our contention that an increase in $\delta^{15} \mathrm{~N}$ values represents an increase in juvenile red snapper trophic position and our hypothesis that red snapper diet shifted in trawled areas are supported by gut content data (Wells et al. 2008b). Wells et al. (2008b) found that juvenile red snapper in trawled areas had higher percentages of fish and mysid shrimp in their guts than did red snapper captured from nontrawled areas. More studies are needed to determine (1) how red snapper trophic position is affected by trawling and (2) the relative contributions of an increase in trophic position and sediment disturbance to elevated $\mathrm{Hg}$ concentrations in juvenile red snapper.

We interpret our results to mean that the presence of commercial shrimp trawling was the primary factor responsible for differences in red snapper $\mathrm{Hg}$ concentrations and $\delta^{15} \mathrm{~N}$ values between trawled and nontrawled subregions for a given habitat type. Factors other than trawling and habitat type, such as depth differences among study sites, may have affected our results. However, this is unlikely because although $\mathrm{Hg}$ concentrations and $\delta^{15} \mathrm{~N}$ values were consistently higher for samples from the trawled subregion, depth differences between trawled and nontrawled habitat types were not consistent. The depth of sand habitat was greater in the trawled subregion than in the nontrawled subregion, but the depths of shell and reef habitats were greater in the nontrawled subregion than in the trawled subregion. Moreover, mean depth differences between trawled and nontrawled subregions for a given habitat type were minimal (range of means $=5-8 \mathrm{~m}$ ).

Habitat-specific differences in $\mathrm{Hg}$ concentrations of juvenile red snapper were size dependent and generally weak. The lack of a strong habitat-specific pattern in red snapper $\mathrm{Hg}$ concentrations is surprising, because
TABLE 2.-Least-squares means $( \pm \mathrm{SE})$ of total mercury $(\mathrm{Hg})$ concentration (ng/g dry weight) and stable nitrogen isotope ratio $\left(\delta^{15} \mathrm{~N} ; \%\right.$ o $)$ in juvenile red snapper collected from sand, shell, and reef habitat types within trawled and nontrawled subregions of the northern Gulf of Mexico continental shelf in 2004 (significant post hoc differences: $* P<0.05)$.

\begin{tabular}{llccc}
\hline Habitat type & Subregion & $n$ & $\mathrm{Hg}$ & $\delta^{15} \mathrm{~N}$ \\
\hline Sand & Trawled & 24 & $148.2 \pm 8.7$ & $13.7 \pm 0.1$ \\
Sand & Nontrawled & 20 & $137.7 \pm 5.4$ & $13.5 \pm 0.1$ \\
Shell & Trawled & 26 & $162.5 \pm 5.1^{*}$ & $13.8 \pm 0.1^{*}$ \\
Shell & Nontrawled & 25 & $137.2 \pm 4.9^{*}$ & $13.5 \pm 0.1^{*}$ \\
Natural reef & Trawled & 11 & $141.9 \pm 8.4$ & $13.8 \pm 0.1$ \\
Natural reef & Nontrawled & 19 & $121.7 \pm 8.2$ & $13.4 \pm 0.1$ \\
\hline
\end{tabular}

$\mathrm{MeHg}$ production in marine ecosystems is a function of sediment characteristics like grain size and organic carbon content (Mason and Lawrence 1999; Hammerschmidt and Fitzgerald 2004, 2006; Hung and Chmura 2006). Seabed characterization of our study sites identified differences in grain size, organic carbon content, and carbonate content among sand, shell, and reef habitats (Dufrene 2005); all of these factors could affect $\mathrm{MeHg}$ production. Despite differences in sediment characteristics, we found no consistent differences in red snapper $\mathrm{Hg}$ concentrations among habitats. However, caution should be used in generalizing our results to other nearshore marine habitats. Due to limited replication in this study, we do not know whether the habitat effect on $\mathrm{Hg}$ concentrations in juvenile red snapper is absent throughout the GOM or only absent at the sites we examined.

Results from this study suggest that the presence of commercial shrimp trawling does not increase juvenile red snapper $\mathrm{Hg}$ concentrations to levels that would cause a public health concern; this finding is not surprising considering the small size of fish examined in this study. However, our study demonstrates that $\mathrm{Hg}$ concentrations are elevated in juvenile red snapper from northern GOM continental shelf areas where commercial shrimp trawling occurs. Given the intense fishing effort throughout the northern GOM shelf and the ability of $\mathrm{Hg}$ to bioaccumulate and biomagnify, more research focusing on $\mathrm{Hg}$ dynamics of recreationally and commercially important species is needed.

\section{Acknowledgments}

Funding for this project was provided by National Sea Grant (Grant NA16RG2249) and a Marine Fisheries Initiative grant (Grant NA17FF2875) to J.H.C. We thank the NOAA NMFS laboratory in Pascagoula, Mississippi, for providing field assistance, equipment, and boat time aboard the R/V Caretta. We are grateful to Leo Newland for providing access to 

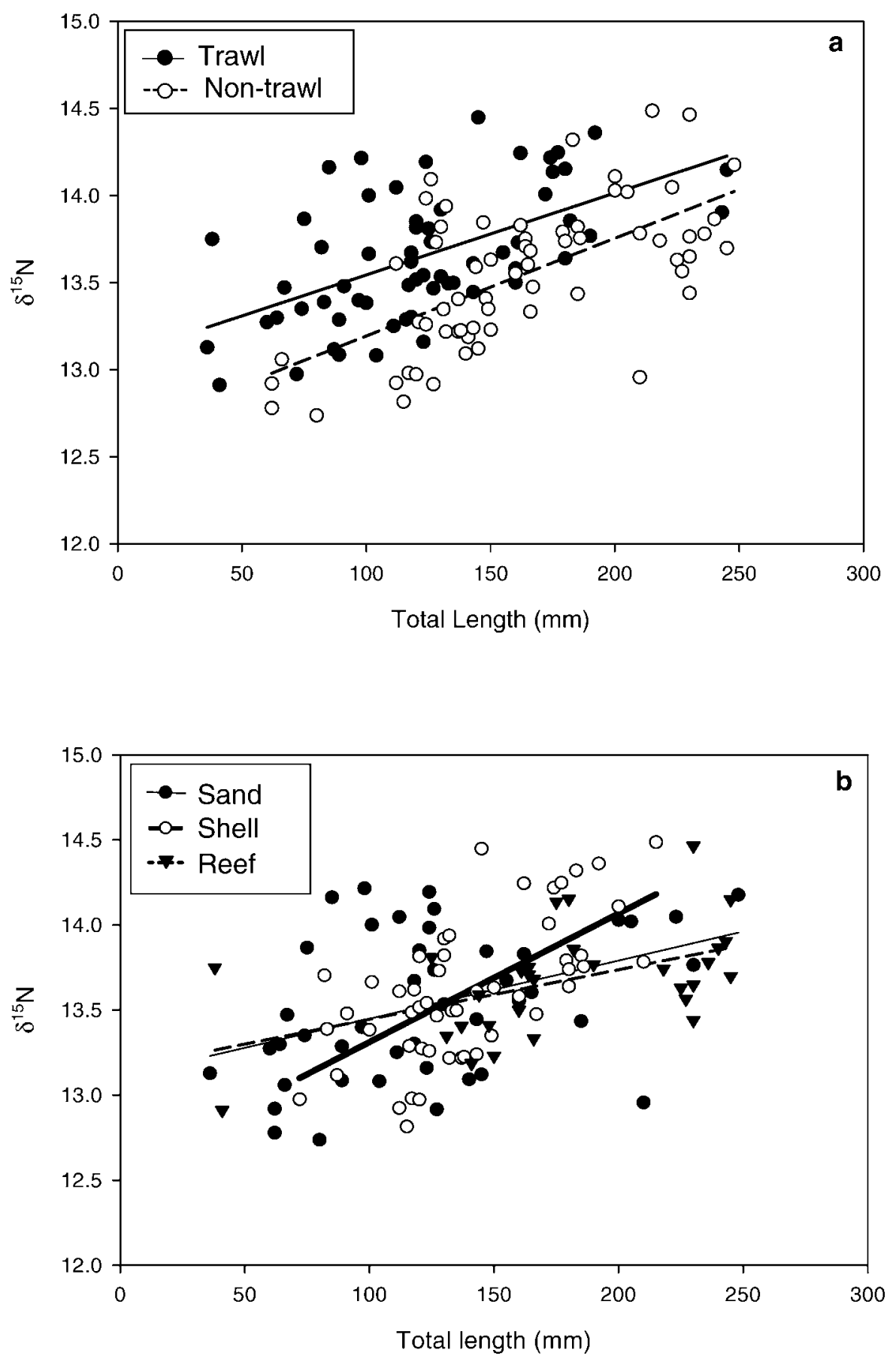

FIGURE 6.- Relationship between stable nitrogen isotope ratio $\left(\delta^{15} \mathrm{~N} ; \%\right.$ ) and total length $(\mathrm{mm})$ of juvenile red snapper collected in 2004 from (a) trawled and nontrawled subregions and (b) sand, shell, and natural-reef habitat types of the northern Gulf of Mexico continental shelf. 
Texas Christian University's Hg analysis facilities and to Brian Fry for $\delta^{15} \mathrm{~N}$ analysis and guidance at the initial stages of this project. David Cross provided statistical advice, and Ray Drenner provided helpful comments on an earlier draft of this manuscript. We would also like to thank three anonymous reviewers for their comments and suggestions, which greatly improved this manuscript.

\section{References}

Bank, M. S., E. Chesney, J. P. Shine, A. Maage, and D. B. Senn. 2007. Mercury bioaccumulation and trophic transfer in sympatric snapper species from the Gulf of Mexico. Ecological Applications 17:2100-2110.

Baron, R. M., and D. A. Kenny. 1986. The moderator mediator variable distinction in social psychologicalresearch-conceptual, strategic, and statistical considerations. Journal of Personality and Social Psychology 51:1173-1182.

Bellas, J., R. Ekelund, H. P. Halldorsson, M. Berggren, and A. A. Granmo. 2007. Monitoring of organic compounds and trace metals during a dredging episode in the Gota Alv estuary (southwestern Sweden) using caged mussels. Water Air and Soil Pollution 181:265-279.

Benoit, J. M., D. H. Shull, P. Robinson, and L. R. Ucran. 2006. Infaunal burrow densities and sediment monomethyl mercury distributions in Boston Harbor, Massachusetts. Marine Chemistry 102:124-133.

Bloom, N. S., G. A. Gill, S. Cappellino, C. Dobbs, L. McShea, C. Driscoll, R. Mason, and J. Rudd. 1999. Speciation and cycling of mercury in Lavaca Bay, Texas, sediments. Environmental Science and Technology 33:7-13.

Bloom, N. S., and B. K. Lasorsa. 1999. Changes in mercury speciation and the release of methyl mercury as a result of marine sediment dredging activities. Science of the Total Environment 237-238:379-385.

Brant, R. 1990. Comparing classical and resistant outlier rules. Journal of the American Statistical Association 85:10831090.

Cabana, G., and J. B. Rasmussen. 1994. Modeling food chain structure and contaminant bioaccumulation using stable nitrogen isotopes. Nature (London) 372:255-257.

Cai, Y., J. R. Rooker, G. Gill, and J. Turner. 2007. Bioaccumulation of mercury in pelagic fishes from the northern Gulf of Mexico. Canadian Journal of Fisheries and Aquatic Sciences 64:1-12.

Clarkson, T. W. 2002. The three modern faces of mercury. Environmental Health Perspectives 110:11-23.

Day, R. W., and G. P. Quinn. 1998. Comparisons of treatments after an analysis of variance in ecology. Ecological Monographs 59:433-463.

Dufrene, T. A. 2005. Geological variability and holocene sedimentary record on the northern Gulf of Mexico inner to mid-continental shelf. Master's thesis. Louisiana State University, Baton Rouge.

Eggleton, J., and K. V. Thomas. 2004. A review of factors affecting the release and bioavailability of contaminants during sediment disturbance events. Environment International 30:973-980.

Fitzgerald, W. F., and C. H. Lamborg. 2003. Geochemistry of mercury in the environment. Pages 107-148 in B.
Sherwood Lollar, editor. Treatise on geochemistry, volume 9. Elsevier, New York.

Fry, B. 2007. Coupled N, C, and S stable isotope measurements using a dual-column gas chromatography system. Rapid Communications in Mass Spectrometry 21:750-756.

Hall, B. D., R. A. Bodaly, R. J. P. Fudge, J. W. M. Rudd, and D. M. Rosenberg. 1997. Food as the dominant pathway of methylmercury uptake by fish. Water Air and Soil Pollution 100:13-24.

Hammerschmidt, C. R., and W. F. Fitzgerald. 2004. Geochemical controls on the production and distribution of methylmercury in near-shore marine sediments. Environmental Science and Technology 38:1487-1495.

Hammerschmidt, C. R., and W. F. Fitzgerald. 2006. Methylmercury cycling in sediments on the continental shelf of southern New England. Geochimica et Cosmochimica Acta 70:918-930.

Hung, G. A., and G. L. Chmura. 2006. Mercury accumulation in surface sediments of salt marshes of the Bay of Fundy. Environmental Pollution 142:418-431.

Jackson, T. A. 1997. Long-range atmospheric transport of mercury to ecosystems and importance of anthropogenic emissions: a critical review and evaluation of the published evidence. Environmental Reviews 5:99-120.

Kaiser, M. J., and B. E. Spencer. 1994. Fish scavenging behaviour in recently trawled areas. Marine Ecology Progress Series 112:41-49.

Kenchington, E. L., D. C. Gordon, Jr., C. Bourbonnais-Boyce, K. G. MacIsaac, K. D. Gilkinson, D. L. McKeown, and W. P. Vass. 2005. Effects of experimental otter trawling on the feeding of demersal fish on Western Bank, Nova Scotia. Pages 391-409 in P. W. Barnes and J. P. Thomas, editors. Benthic habitats and the effects of fishing. American Fisheries Society, Symposium 41, Bethesda, Maryland.

Kennicutt, M. C., W. W. Schroeder, and J. M. Brooks. 1995. Temporal and spatial variations in sediment characteristics on the Mississippi-Alabama continental shelf. Continental Shelf Research 15:1-18.

Lindqvist, O., K. Johansson, M. Aastrup, A. Andersson, L. Bringmark, G. Hovsenius, L. Hakanson, A. Iverfeldt, M. Meili, and B. Timm. 1991. Mercury in the Swedish environment. Water Air and Soil Pollution 55:1-261.

Link, J. 1997. Untrawlable bottom in shrimp statistical zones of the northwest Gulf of Mexico. U.S. National Marine Fisheries Service Marine Fisheries Review 59(4):33-36.

Mason, R. P., and G. A. Gill. 2005. Mercury in the marine environment. Pages 179-216 in M. B. Parsons and J. B. Percival, editors. Mercury: sources, measurements, cycles, and effects. Mineralogical Association of Canada, Halifax, Nova Scotia.

Mason, R. P., and A. L. Lawrence. 1999. Concentration, distribution, and bioavailability of mercury and methylmercury in sediments of Baltimore Harbor and Chesapeake Bay, Maryland, USA. Environmental Toxicology and Chemistry 18:2438-2447.

McCawley, J. R., J. H. Cowan, Jr., and R. L. Shipp. 2006. Feeding periodicity and prey habitat preference of red snapper, Lutjanus campechanus (Poey, 1860), on Alabama artificial reefs. Gulf of Mexico Science 1/ 2:14-27.

McClain, W. C., M. M. Chumchal, R. W. Drenner, and L. W. 
Newland. 2006. Mercury concentrations in fish from Lake Meredith, Texas: implications for the issuance of fish consumption advisories. Environmental Monitoring and Assessment 123:249-258.

Miles, C. J., H. A. Moye, E. J. Phillips, and B. Sargent. 2001. Partitioning of monomethylmercury between freshwater algae and water. Environmental Science and Technology 35:4277-4282.

Minagawa, M., and E. Wada. 1984. Stepwise enrichment of ${ }^{15} \mathrm{~N}$ along food chains: further evidence and the relation between $\delta^{15} \mathrm{~N}$ and animal age. Geochimica et Cosmochimica Acta 48:1135-1140.

Morel, F. M. M., A. M. L. Kraepiel, and M. Amyot. 1998. The chemical cycle and bioaccumulation of mercury. Annual Review of Ecology and Systematics 29:543-566.

Munthe, J., R. A. Bodaly, B. A. Branfireun, C. T. Driscoll, C. C. Gilmour, R. Harris, M. Horvat, M. Lucotte, and O. Malm. 2007. Recovery of mercury contaminated fisheries. Ambio 36:33-44

NRC (National Research Council). 2000. Toxicological effects of methylmercury. National Academy Press, Washington, D.C.

NRC (National Research Council). 2002. Effects of trawling and dredging on seafloor habitat. National Academy Press, Washington, D.C.

Ott, R. L. 1993. An introduction to statistical methods and data analysis, 4th edition. Wadsworth, Belmont, California.

Pacyna, J. M., and E. G. Pacyna. 2005. Anthropogenic sources and global inventory of mercury emissions. Pages 43-56 in M. B. Parsons and J. B. Percival, editors. Mercury: sources, measurements, cycles, and effects. Mineralogical Association of Canada, Halifax, Nova Scotia.

Patella, F. 1975. Water surface area within statistical subareas used in reporting Gulf coast shrimp data. U.S. National Marine Fisheries Service Marine Fisheries Review 37(12):22-24

Patterson, W. F., C. A. Wilson, S. J. Bentley, J. H. Cowan, Jr., T. Henwood, Y. C. Allen, and T. A. Dufrene. 2005. Delineating juvenile red snapper habitat on the northern Gulf of Mexico continental shelf. Pages 277-288 in P. W. Barnes and J. P. Thomas, editors. Benthic habitats and the effects of fishing. American Fisheries Society, Symposium 41, Bethesda, Maryland.

Peterson, B. J., and B. Fry. 1987. Stable isotopes in ecosystem studies. Annual Review of Ecology and Systematics 18:293-320.

Quinn, G. P., and M. J. Keough. 2002. Experimental design and data analysis for biologists. Cambridge University Press, Cambridge, UK.

SAS Institute. 2006. Statistics, version 9.1. SAS Institute, Cary, North Carolina

Schroeder, W. W., A. W. Shultz, and J. J. Dindo. 1988. Innershelf hardbottom areas, northeastern Gulf of Mexico. Gulf Coast Association of Geological Societies Transaction 38:535-541.

Szedlmayer, S. T., and J. C. Howe. 1997. Substrate preference in age-0 red snapper, Lutjanus campechanus. Environmental Biology of Fishes 50:203-207.

Thrush, S. F., and P. K. Dayton. 2002. Disturbance to marine benthic habitats by trawling and dredging: implications for marine biodiversity. Annual Review of Ecology and Systematics 33:449-473.

Tsui, M. T. K., and W. X. Wang. 2004. Uptake and elimination routes of inorganic mercury and methylmercury in Daphnia magna. Environmental Science and Technology 38:808-816.

Ullrich, S. M., T. W. Tanton, and S. A. Abdrashitova. 2001. Mercury in the aquatic environment: a review of factors affecting methylation. Critical Reviews in Environmental Science and Technology 31:241-293.

University of Georgia Marine Extension Service and National Marine Fisheries Service Harvesting Branch. 2003. Wild sea turtle escapes and dolphin/trawl interactions. DVD video. Marine Advisory Services, Brunswick, Georgia.

USEPA (United States Environmental Protection Agency). 1998. Method 7473: mercury in solids and solutions by thermal decomposition, amalgamation, and atomic absorption spectrophotometry. USEPA, Washington, D.C.

USEPA (United States Environmental Protection Agency). 2006. EPA's roadmap for mercury. USEPA, Washington, D.C.

Wassenberg, T. J., and B. J. Hill. 1987. Feeding by the sand crab, Portunus pelagicus, on material discarded from prawn trawlers in the Moreton Bay, Australia. Marine Biology 95:387-393.

Wiener, J. G., D. P. Krabbenhoft, G. H. Heinz, and A. M. Scheuhammer. 2003. Ecotoxicology of mercury. Pages 409-463 in D. J. Hoffman, B. A. Rattner, G. A. Burton, Jr., and J. Cairns, Jr., editors. Handbook of ecotoxicology, 2nd edition. Lewis Publishers, Boca Raton, Florida

Wells, R. J. D., K. M. Boswell, J. H. Cowan, Jr., and W. F. Patterson. 2008a. Size selectivity of sampling gears targeting red snapper in the northern Gulf of Mexico. Fisheries Research 89:294-299.

Wells, R. J. D., J. H. Cowan, Jr., and B. Fry. 2008b. Feeding ecology of red snapper, Lutjanus campechanus, in the northern Gulf of Mexico. Marine Ecology Progress Series 361:213-225.

Wells, R. J. D., J. H. Cowan, Jr., and W. F. Patterson. 2008c. Habitat use and the effect of shrimp trawling on fish and invertebrate communities over the northern Gulf of Mexico continental shelf. ICES Journal of Marine Science 65: (doi: 10.1093/icesjms/fsn145).

Woods, M. W., J. H. Cowan, Jr., and D. L. Nieland. 2007. Demographic differences in northern Gulf of Mexico red snapper reproductive maturation: implications for the unit stock hypothesis. Pages 217-227 in W. F. Patterson, III, J. H. Cowan, Jr., G. R. Fitzhugh, and D. L. Nieland, editors. Red snapper ecology and fisheries in the U.S. Gulf of Mexico. American Fisheries Society, Symposium 60, Bethesda, Maryland

Workman, I. K., and D. G. Foster. 1994. Occurrence and behavior of juvenile red snapper, Lutjanus campechanus, on commercial shrimp fishing grounds in the northeastern Gulf of Mexico. U.S. National Marine Fisheries Service Marine Fisheries Review 56(2):9-11.

Workman, I. K., A. Shah, D. G. Foster, and B. Hataway. 2002. Habitat preferences and site fidelity of juvenile red snapper (Lutjanus campechanus). ICES Journal of Marine Science 59:S43-S50. 